\section{Parallel Carbonylation and Decarbonylative Heck Reaction on Palladium/Carbon}

\section{Key words}

\section{carbonylation}

Mizoroki-Heck reaction

cinnamaldehydes

palladium on carbon

palladium catalysis

$\mathrm{Pd} / \mathrm{C}(10 \mathrm{~mol} \% \mathrm{Pd})$

$\mathrm{Na}_{2} \mathrm{CO}_{3}$ (2 equiv)<smiles>O=Cc1ccc(C=O)cc1</smiles>

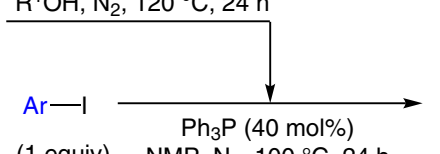<smiles>O=C([Te])O[Tl]</smiles>

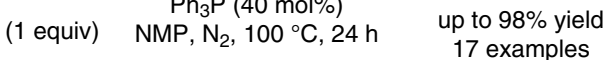<smiles>[R7]c1ccc(C(=O)OCCC)cc1</smiles>

$\mathrm{R}^{2}=\mathrm{H}, 88 \%$ yield $R^{2}=A c, 85 \%$ yield $\mathrm{R}^{2}=\mathrm{NO}_{2}, 87 \%$ yield $\mathrm{R}^{2}=\mathrm{OMe}, 75 \%$ yield<smiles>COc1ccc(C(=O)O)cc1</smiles>

$\mathrm{R}^{1}=\mathrm{Et}, 59 \%$ yield $\mathrm{R}^{1}=n-\operatorname{Pr}, 29 \%$ yield $\mathrm{R}^{1}=n-\mathrm{Bu}, 30 \%$ yield $\mathrm{R}^{1}=n$-Pent, $64 \%$ yield $\mathrm{R}^{1}=\mathrm{Me}, 54 \%$ yield<smiles>O=C1NC(=O)c2ccccc21</smiles><smiles>CCCOC(=O)c1ccncc1</smiles>

$\mathrm{R}^{3}=\mathrm{H}, 85 \%$ yield (from 2- $\mathrm{HOCH}_{2} \mathrm{C}_{6} \mathrm{H}_{4} \mathrm{I}$ in $i-\mathrm{PrOH}$ ) (from 2- $\mathrm{NH}_{2} \mathrm{COC}_{6} \mathrm{H}_{4}$ l in $i-\mathrm{PrOH}$ ) $\mathrm{R}^{3}=\mathrm{Me}, 98 \%$ yield (from 2- $\mathrm{HOCH}_{2}-4-\mathrm{MeC}_{6} \mathrm{H}_{3}$ in $i-\mathrm{PrOH}$ )

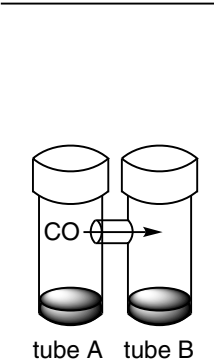

tube $\mathrm{A}$<smiles>[R7]c1ccc(/C=C/C=O)cc1</smiles>

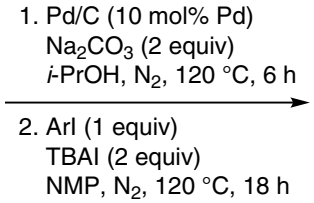

NMP, $\mathrm{N}_{2}, 120^{\circ} \mathrm{C}, 18 \mathrm{~h}$

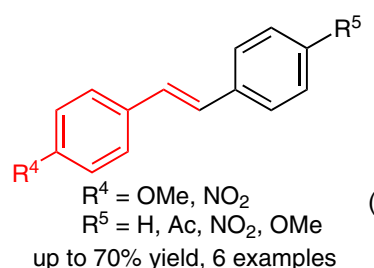

(2)<smiles>NC(=O)c1ccccc1I</smiles>

$\mathrm{Pd} / \mathrm{C}(10 \mathrm{~mol} \% \mathrm{Pd})$ $\mathrm{Ph}_{3} \mathrm{P}$ (40 mol\%)<smiles>O=C1OCc2ccccc21</smiles>

up to $89 \%$ yield<smiles>O=C1NC(=O)c2ccccc21</smiles>

$49 \%$ yield
Significance: Palladium on carbon $(\mathrm{Pd} / \mathrm{C})$ catalyzed the carbonylation of aryl iodides with terephthalaldehyde as a CO source to give the corresponding products in up to $98 \%$ yield (eq. $1 ; 17$ examples). A simultaneous parallel decarbonylative Mizoroki-Heck reaction of cinnamaldehydes with iodobenzenes (tube A) and carbonylation of 2-iodobenzyl alcohol or 2-iodobenzamide with the CO generated in situ (tube B) were carried out in the presence of $\mathrm{Pd} / \mathrm{C}$ in an $\mathrm{H}$-shaped tube to give trans-stilbenes and a phthalide or phthalimide, respectively (eq. 2; 6 examples).

SYNFACTS Contributors: Yasuhiro Uozumi, Go Hamasaka Synfacts 2017, 13(09), 0989 Published online: 18.08.2017 Dol: 10.1055/s-0036-1591152; Reg-No.: Y10017SF
Comment: No recyclability of $\mathrm{Pd} / \mathrm{C}$ was observed in the parallel decarbonylative Mizoroki-Heck reaction of 4-methoxycinnamaldehyde with iodobenzene and carbonylation of 2-iodobenzyl alcohol (first reuse: 4-methoxy-trans-stilbene: 0\% yield; phthalide: trace). 